Does Pharmacotherapy Reduce the Rate of Decline of Lung Function in COPD? Peer-reviewed author version

Decramer, Marc \& MOLENBERGHS, Geert (2009) Does Pharmacotherapy Reduce the Rate of Decline of Lung Function in COPD?. In: AMERICAN JOURNAL OF RESPIRATORY AND CRITICAL CARE MEDICINE, 179(2). p. 171-171.

DOI: 10.1164/ajrccm.179.2.171

Handle: http://hdl.handle.net/1942/9223 


\section{Does Pharmacotherapy reduce Rate of Decline of Lung Function in COPD?}

We read with great interest the results of the tertiary analysis of the TORCH-study ${ }^{1}$, suggesting that pharmacotherapy has an effect on the progression of the disease in COPD. This is an important observation of great potential interest to our patients. Given this relevance, we would like to encourage the authors to provide more detailed information in two areas.

The first area is the effect size. There are four previous landmark studies on the effects of inhaled steroids on rate of lung function decline $e^{2-5}$. None of these studies showed a statistically significant reduction in rate of decline. Admittedly, none of them was sufficiently powered. The number of patients involved ranged from 145 to 643 per group, which falls short by a factor of two at least. However, the effect size was considerably smaller than observed in the present analysis, ranging from -4 to $12 \mathrm{~mL} /$ year. Hence, it would be interesting if the authors would present their views on why in the current study the effect size seems disproportionately larger.

The second area concerns statistics. From the numbers given at the bottom of Fig.2 of the present publication ${ }^{1}$ and the comparison to Fig. panel $\mathrm{E}$ of the original publication ${ }^{6}$, it appears that the patients who only had an FEV1 measurement at baseline and dropped out of the study before 6 months of follow-up, were not included in the analysis. This appears to make sense intuitively, because the decline of interest was between 6 and 36 months. However, in likelihood-based analysis, such as a linear mixed effect model, these patients should have been included in view of the method's validity under conditions of data missing at random ${ }^{7}$. They thus may influence the decline between 6 and 36 months. In addition, the number of patients excluded from the analysis is considerable, ranging from $9.2 \%$ in the combination treatment group to $\mathbf{1 7 . 3 \%}$ in the placebo group. Because as observed in several trials before the drop-out was not completely at random, this exclusion might have influenced the active treatments and the placebo groups differentially. Hence, it would really be interesting to provide an analysis with these patients added to the regression analysis. Along the same lines, since only adjusted rates of decline were reported in the text and tables, it would also be relevant to explain how rates of decline were adjusted and whether the observed effect was also present with unadjusted rates of decline. 


\section{Marc Decramer ${ }^{1}$ and Geert Molenberghs ${ }^{2}$}

\section{${ }^{1}$ Respiratory Division, University Hospital Leuven, Belgium and ${ }^{2}$ Interuniversity Institute for Biostatistics, Universities of Hasselt and Leuven, Belgium.}

\section{References}

1. Celli BR, Thomas NE, Anderson JA, Ferguson GT, Jenkins C, Jones PW, Vestbo J, Knobil K, Yates JC and Calverley PM. Effect of pharmacotherapy on rate of decline of lung function in COPD. Am J Respir Crit Care Med 2008;

2. Vestbo J, Sørensen T, Lange P, Brix A, Torre P and Viskum K. Long-term effect of inhaled budesonide in mild and moderate chronic obstructive pulmonary disease: a randomized controlled trial. Lancet 1999; 353: 1819-1823.

3. Pauwels RA, Löfdahl CG, Laitinen LA, Schouten JP, Postma DS, Pride NB, Ohlson SV. Long-term treatment with inhaled budesonide in persons with mild chronic obstructive pulmonary disease who continue smoking. N Eng J Med 1999; 340: 1948-1953.

4. Lung Health Research Study Group. Effect of inhaled triamcinolone on the decline in pulmonary function in chronic obstructive pulmonary disease. N Eng J Med 2000; 343: 1902-1909.

5. Burge PS, Calverley PM, Jones PW, Spencer S, Anderson JA, and Maslen TK. Randomised, double blind, placebo-controlled study of fluticasone in patients with moderate to severe chronic obstructive pulmonary disease: the ISOLDE trial. BMJ 2000; 320: 1297-1303.

6. Calverley PMA, Anderson JA, Celli B, Ferguson GT, Jenkins C, Jones PW, Yates JC, and Vestbo J. Salmeterol and fluticasone propionate and survival in chronic obstructive pulmonary disease. N Eng J Med 2007; 356: 775-89.

7. Verbeke G and Molenberghs G. Linear Mixed Models for Longitudinal Data. New York: Springer, 2000.

Word count: 399 